\title{
Arquivos visuais relacionados ao vírus Zika: imagens no Instagram como parte da constituição de uma memória da epidemia
}

\author{
Visual archives concerning Zika virus: images on Instagram as part of the \\ constitution of an epidemic memory
}

\section{Archivos visuales relacionados con el virus Zika: imágenes de Instagram como parte de la constitución de una memoria de la epidemia}

\author{
Michele Nacif Antunes | michelenantunes@gmail.com \\ Universidade Federal do Espírito Santo (UFES), Programa de Pós-Graduação em Saúde Coletiva (PPGSC). Vitória, ES, Brasil.
}

Wedencley Alves | wedencley@gmail.com

Universidade Federal de Juiz de Fora, Faculdade de Comunicação. Juiz de Fora, MG, Brasil.

Fábio Gomes Goveia | fabiogv@gmail.com

Universidade Federal do Espírito Santo (Ufes), Departamento de Comunicação Social, Laboratório de Estudos sobre Imagem e Cibercultura (Labic). Vitória, ES, Brasil.

Adauto Emmerich Oliveira | adautoemmerich@terra.com.br

Universidade Federal do Espírito Santo (UFES), Programa de Pós-Graduação em Saúde Coletiva (PPGSC). Vitória, ES, Brasil.

Janine Miranda Cardoso |janinecardoso.fiocruz@gmail.com

Fundação Oswaldo Cruz, Instituto de Comunicação e Informação Científica e Tecnológica em Saúde (Icict), Laboratório de Comunicação e Saúde (Laces), Rio de Janeiro, RJ, Brasil.

\section{Resumo}

Este artigo baseia-se em um estudo que teve como objetivo analisar as imagens que despertam maior interesse e maior número de compartilhamentos por parte dos internautas a partir do dispositivo em rede Instagram sobre a epidemia de Zika. O recorte temporal abrange novembro e dezembro de 2015, ou seja, os dois meses posteriores à revelação por pesquisadores e autoridades médicas de que a infecção pelo vírus Zika poderia estar associada a casos de microcefalia diagnosticados em recém-nascidos. No estudo, recorremos ao ImageCloud, um aplicativo desenvolvido pelo Laboratório de Estudos sobre Imagem e Cibercultura, da Universidade Federal do Espírito Santo e que permite visualizar uma grande quantidade de imagens em bases de dados, como, por exemplo, nas redes sociais. A análise foi encaminhada a partir dos pressupostos teóricos da análise do discurso.

Palavras-chave: epidemia; Zika; imagem; redes sociais; Instagram; análise do discurso. 


\begin{abstract}
This article bases on a study aiming to analyze the images on Zika virus epidemic that aroused a great public interest and a great number of sharings from the device Instagram. The period of analysis covers November and December 2015, namely two months after researchers and medical authorities have proclaimed that the infection could be associated with cases of microcephaly diagnosed in newborns. This study used the ImageCloud, a tool developed by Laboratório de Estudos sobre Imagem e Cibercultura, da Universidade Federal do Espírito Santo (Laboratory for studies of Image and Cyberculture, from Federal University of Espirito Santo), which allows us to visualize a lot of images in databases like, for example, onsocial networks. The theoretical base used to the analysis in question was the discourse analysis.
\end{abstract}

Keywords: epidemic; Zika; images; social networks; Instagram; discourse analysis.

\title{
Resumen
}

El presente artículo es basado en estudio que ha tenido como finalidad analizar las imágenes que han despertado gran interese y han sido compartidas por los internautas a partir del dispositivo en red Instagram acerca de la epidemia de Zika. El recorte temporal abarcó noviembre y diciembre de 2015, es decir, los dos meses posteriores a la revelación por investigadores y autoridades médicas de que la infección por el virus podría estar asociada a casos de microcefalia diagnosticados en recién nacidos. En el estudio, hemos recurrido a ImageCloud, una aplicación desarrollada por el Laboratório de Estudos sobre Imagem e Cibercultura, da Universidade Federal do Espírito Santo (Laboratorio de estudios acerca de la imagen y cibercultura, de la Universidad Federal de Espírito Santo), y que permite visualizar una cantidad grande de imágenes en bases de datos, como, por ejemplo, en las redes sociales. El análisis ha sido realizado a partir de los presupuestos teóricos del análisis del discurso.

Palabras clave: epidemia; Zika; imagen; redes sociales; Instagram; análisis de discurso.

Contribuição dos autores:

Aquisição dos dados, análise e redação: Michele Nacif

Redação, análise dos dados e revisão crítica do conteúdo: Wedencley Alves

Coleta e organização dos dados para análise e redação do manuscrito: Fabio Gouveia

Redação e revisão crítica do conteúdo: Adauto Emmerich

Análise, redação e revisão crítica do conteúdo: Janine Cardoso

Declaração de conflito de interesses: Os autores declaram que não há qualquer conflito de interesses relacionado à produção e circulação do artigo.

Fontes de financiamentos: A pesquisa não contou com fontes específicas de financiamento.

Agradecimento/Contribuições adicionais: Laboratório de Estudos sobre Imagem e Cibercultura, da Universidade Federal do Espírito Santo (UFES), pela coleta e organização do material para análise.

Histórico do artigo: Submissão: 12 ago.2016 | Aprovação: 06 set.2016 | Publicado: 30 set.2016

Licença CC BY-NC atribuição não comercial. Com essa licença é permitido acessar, baixar (download), copiar, imprimir, compartilhar, reutilizar e distribuir os artigos, desde que para uso não comercial e com a citação da fonte, conferindo os devidos créditos de autoria e menção à Reciis. Nesses casos, nenhuma permissão é necessária por parte dos autores ou dos editores. 


\section{Introdução}

Há muito tempo, a iconografia religiosa ${ }^{\mathrm{i}}$ ajudava as pessoas comuns a interpretar as epidemias. Foi assim que a peste bubônica, nos quatrocentos anos (1347-1720) que atemorizaram o imaginário europeu, chegou a ser comparada a centelhas implacáveis, ao fogo que devastou cidades, a tempestades de aflições, a flechas que atravessavam os corpos e levavam suas almas. Por vezes, as pestes eram vistas como castigo divino para lembrar aos homens que estavam em falta com Deus.

Como diz Delumeau, em História do medo no Ocidente ${ }^{1}$, as flechas da epidemia aparecem pela primeira vez "sobre um painel do altar dos carmelitas descalços (1424) de Göttingen", como castigo. No quadro, "Cristo as lança em chuva densa sobre os homens. Dezessete personagens são traspassados por elas. No entanto, vários outros são protegidos pelo grande manto da Virgem”.

Mas as explicações religiosas perderam muito do seu vigor. Outra discursividade se impôs, a das ciências biomédicas, embora não seja descabido dizer que sobrevivem ainda traços das representações tradicionais sobre as epidemias, nem que sejam metaforizadas em preceitos morais ou, mais precisamente, moralistas.

Nos anos 1980, por exemplo, em muitos lugares, a interpretação moral da epidemia de HIV disputou com os discursos científicos o direito à verdade. E mesmo esses discursos foram atravessados - se ainda não o são - por resquícios de uma interpretação moral-religiosa para dar conta, por exemplo, dos outrora designados "grupos de risco".

Ainda assim a iconografia religiosa perde espaço, como materialidade significante própria à interpretação das doenças e das epidemias para outras 'iconografias' contemporâneas que dizem respeito aos discursos hegemônicos da ciência. A representatividade social da imagem de um vírus pode ser, hoje, mais atemorizante do que centelhas, tempestades e flechas.

O presente artigo discute quais foram as imagens mais curtidas num desses acervos da 'iconografia' ultramoderna: o Instagram. Dispositivo de compartilhamento de imagens, essa invenção da era das redes pode revelar, se olhado discursivamente, que sentidos as sociedades contemporâneas mobilizam para compreender as suas pestes.

Mais precisamente no estudo aqui analisado, tratamos da epidemia do vírus Zika, que de pouca preocupação despertada desde a sua chegada ao país, posteriormente transformou-se num pesadelo, principalmente para mulheres grávidas após a revelação de que casos de microcefalia diagnosticada em recém-nascidos poderiam estar associados à infecção pelo vírus. Tendo como vetor o mosquito Aedes aegypti, já tão familiar no território brasileiro, parte da sociedade deparou-se com a sensação de desamparo e incerteza.

A partir de dispositivos teóricos da análise do discurso (linha Pêcheux-Orlandi), podemos considerar que as imagens com mais acesso e mais curtidas significariam maior ou menor adesão a discursos por parte daqueles que construiriam uma espécie de enunciação coletiva sobre a epidemia. O que tentamos fazer é compreender que práticas e formações discursivas prevaleceram durante os dois primeiros meses - novembro e dezembro de 2015 - após o anúncio pelo Ministério da Saúde (MS) e demais autoridades médicas, das suspeitas de associação entre a infecção e malformações em recém-nascidos.

Para isso, foram necessárias três etapas anteriores à análise propriamente dita. A determinação de um descritor, o termo \#zikavirus; a utilização do ImageCloud, que nos trouxe uma coleção de imagens, por ordem de maior acesso, a que chamaremos de arquivo analítico; e, a partir deste arquivo, a construção de um corpus restrito.

\footnotetext{
i O termo iconografia (eikon=imagen e grafhia=escrita) é o estudo descritivo da representação visual de símbolos e imagens, sem levar em conta o valor estético que possam ter. Jean Delumeau1, tratando dos episódios de pânico coletivo que foram os surtos de peste negra, afirma que para os homens da Igreja e para os artistas, a peste era representada como uma chuva de flechas abatendo-se de súbito sobre os homens pela vontade de um Deus encolerizado. Essa imagem do flagelo jogado do céu em direção aos homens foi amplamente difundida pela iconografia dos séculos XV e XVI.
} 
O ImageCloud é um aplicativo desenvolvido pelo Laboratório de Estudos sobre Imagem e Cibercultura (Labic), da Universidade Federal do Espírito Santo, e permite visualizar uma grande quantidade de imagens em bases de dados, como, por exemplo, nas redes sociais. A visualização de dados tem como propósito estruturar uma determinada quantidade de informação, tornando possível estabelecer "padrões e relações escondidas diante do caos do montante de dados"2.

A partir da ferramenta foi possível coletar, no período de novembro e dezembro de 2015, as imagens publicadas no Instagram e organizá-las em um mosaico de imagens, permitindo uma visualização linear a partir de um único parâmetro: a quantidade de "curtidas" (ou "likes") nas imagens referentes à hashtag “\#zikavirus”. Desta forma, o ImageCloud possibilita ao pesquisador visualizar o conjunto como um todo, o que se tornou a base desta análise que ora desenvolvemos.

\section{Uma nova epidemia que chega}

O vírus Zika foi isolado pela primeira vez em primatas em Uganda, na floresta Zika em 1947 - vem daí a sua denominação. Entre 1951 e 2013, evidências sorológicas em humanos foram notificadas em países da África, Ásia e Oceania. Nas Américas, o Zika vírus foi identificado unicamente na Ilha de Páscoa, território do Chile, no oceano Pacífico, a $3.500 \mathrm{~km}$ do continente no início de 2014. O vetor é o mosquito Aedes aegypti3.

Foi em maio de 2015 que o vírus Zika chegou ao Brasil. Na ocasião, o Ministério da Saúde declarou que o fato não apresentava maiores riscos, pois a doença não poderia ser fatal como a dengue ${ }^{4}$. Mas em outubro de 2015, o Zika vírus passou a ser não só uma preocupação sutil, mas também uma grande ameaça, quando foi associado, ainda que de forma hipotética, a casos de microcefalia em Pernambuco 5 .

A partir daí, a incidência do vírus foi declarada pelo MS como Emergência em Saúde Pública de Importância $\mathrm{Nacional}^{6}$, um mecanismo previsto para casos que demandem o emprego urgente de medidas de prevenção, controle e contenção de riscos, danos e agravos à saúde pública. Em dezembro do mesmo ano, a Organização Mundial da Saúde (OMS) emitiu alerta mundial, para seus mais de 140 países-membros reforçarem a vigilância ante o eventual crescimento de infecções provocadas pelo Zika vírus. Logo em seguida, foi decretada situação de emergência em saúde pública de importância internacional7 .

A associação do vírus às suspeitas de microcefalia fez com que a nova epidemia passasse a ser um novo acontecimento social, reforçando os sentimentos de imprevisibilidade, de insegurança e incerteza, próprios à sociedade de risco. De acordo com Beck ${ }^{8}$, trata-se de uma sociedade que experimenta de forma dramática a incerteza decorrente da impossibilidade de se tomar decisões apoiadas em experiências passadas. Para essa configuração social contemporânea, as situações novas e inesperadas são vistas como ameaças; a ciência não é suficiente para garantir as certezas, e o Estado é visto como limitado em sua capacidade política e de proteção.

Bauman ${ }^{9}$ acentua que os riscos não estão dissociados de certas relações de poder. Para o autor, há muito mais infortúnios iminentes sendo proclamados do que aqueles que acabam realmente ocorrendo. Assim, podemos esperar que esse ou aquele desastre recentemente anunciado não aconteça. Se os "riscos são líquidos", ou seja, se movem facilmente e não mantêm sua forma com facilidade, pode-se presumir o mesmo em relação à longevidade dos medos que atualmente nos afligem.

Bauman ${ }^{10}$ afirma ainda que é de forma indireta que "as pessoas comuns" tomam consciência dos riscos e ameaças, seja por meio dos prognósticos alarmistas apresentados por experts, e logo, recolhidos, endossados e ampliados por instituições públicas; seja por meio de empresas comerciais e meios de comunicação. Desta forma, é fácil menosprezar ou silenciar os perigos que não prometem ganhos políticos ou financeiros, enquanto outros são altamente inflados ou até inventados. Com isso, o mundo hoje parece muito mais inseguro do que tempos atrás, ainda que as sociedades contemporâneas assistam, cada vez mais, a medidas extraordinárias de segurança ${ }^{10}$. 
Os riscos parecem ser neutros e não intencionais. Seus efeitos parecem aleatórios. Mas não é difícil conceber que haja uma relação íntima entre vulnerabilidade socioeconômica e/ou sociopolítica - como por exemplo, os refugiados de guerra - e a probabilidade de alguém se tornar uma vítima de catástrofes. Os dados do jogo dos riscos são viciados ${ }^{10}$.

\section{Epidemias e o jogo dos sentidos}

Para compreendermos os processos de produção, formulação e circulação de sentidos no campo da saúde, devemos considerar dois fatores de enorme abrangência na sociedade contemporânea: o fato de vivermos em uma sociedade mediada e o fato de presenciarmos uma multiplicação das materialidades semiológicas. Jornais, revistas, TV, rádio, internet e seus veículos, novos modos de interação midiática em dispositivos móveis, todos esses media sobredeterminam de um modo dinâmico e complexo o que compreendemos por saúde, doença, bem e mal-estar, em que pese a experiência íntima e muitas vezes irrepresentável do sofrimento individualii.

O presente artigo tem como objetivo revelar a análise das imagens sobre a epidemia que circularam nos meses de novembro e dezembro de 2015, compartilhadas e curtidas a partir do aplicativo Instagram, que por ser uma construção coletiva, torna-se uma amostragem bastante representativa de como as textualidades visuais em circulação ajudaram a produzir, reproduzir e deslocar sentidos sobre o que foi essa epidemia. As imagens acabaram por constituir uma memória discursiva que, uma vez registrada, tornou-se um arquivo discursivo sobre uma doença até então desconhecida de boa parte do planeta.

O conceito de memória discursiva, proposta num primeiro momento por Courtine ${ }^{12}$ é fruto do desdobramento de reflexões acerca do interdiscurso ${ }^{13}$ em sua relação com o esquecimento. Interdiscurso fora definido como "o todo complexo" das formações discursivas que sustentam todo o dizer. Essas formações discursivas, matrizes de sentido, não estão em relação de igualdade, mas de contradição, de subordinação entre elas. Já a memória discursiva, que para alguns autores não difere de interdiscurso, pode ser compreendida como aquilo que, face a um texto que surge como acontecimento a ler, vem restabelecer os implícitos (quer dizer, mais tecnicamente, os pré-construídos, elementos citados e relatados, discursos transversos etc.) de que sua leitura necessita: a condição legível em relação ao próprio legível ${ }^{14}$.

Compreendemos porque alguns autores como Eni Orlandi parecem não diferir os conceitos de interdiscurso e memória discursiva: simplesmente porque se trata do mesmo processo de sustentação do dizer. Optamos, no entanto, pela distinção ao direcionar nossa discussão para a "memória discursiva da epidemia de Zika", ou seja, aquilo que no interdiscurso contribuiu para a produção de sentido sobre a epidemia.

Toda a discussão sobre interdiscurso e memória discursiva passa por uma reflexão sobre o "esquecimento". Orlandi enuncia de forma clara esta relação: a memória discursiva é também "estruturada pelo esquecimento" 15 . A partir disso, podemos dizer que o arquivo discursivo é estruturado pelo silenciamento, visto que só há arquivo se algo é deixado de fora, interditado.

$\mathrm{O}$ arquivo discursivo, então, passa a ser definido como aquilo que na memória discursiva "mereceu" registro material, seja qual for a materialidade. Sem dúvida, os meios atuais de registro impuseram

ii Cumpre lembrar aqui a distinção feita por Birman ${ }^{11}$ entre sofrimento e dor - física, psíquica, moral etc. O sofrimento é dirigido ao outro. Já a dor, no registro do corpo, incomunicável. O autor defende que, se por um lado, as antigas modalidades de sofrimento eram centradas no conflito psíquico; o mal-estar hoje se evidencia nos registros "do corpo e da ação". Daí o processo de somatização do mal-estar, na forma de dor, problemas "do corpo"; e a insistente "produção da saúde", geralmente medicalizada, tão publicizada pelos meios de comunicação. 
significativas transformações nas relações de sentido e de "poder de arquivo". Buscar no Instagram os sentidos sobre a epidemia de Zika já é por si só o sintoma de uma épocaiii.

É preciso ressaltar que a constituição da textualidade visual obedece a lógicas distintas do ponto de vista da materialidade significante com relação às textualidades linguísticas. Há diferenças sintáticas da imagem em relação aos textos, que vão resultar tanto em diferentes modos de formulação quanto em distintos modos de circulação.

Mas do ponto de vista discursivo, continuamos trabalhando com os dispositivos clássicos previstos na análise do discurso, tanto os teóricos quanto os analíticos. Neste artigo especificamente, avançamos na compreensão sobre a produção de 'arquivo' e de uma 'memória' discursiva de um mal que oferecia poucas referências anteriores. Esta é a nossa entrada de análise.

A materialização de sentidos, seja por meios uni ou multimodais, se dá a partir de uma complexa relação de remissões, retomadas e deslocamentos. A imagem significa o que vemos, mas também o que dizemos; a significação pela imagem só é possível graças à contínua remissão às imagensjá constituídas, a uma memória icônica, mas também à memória discursiva dos dizeres, da língua. Assim, se todo enunciado se insere em uma rede de memórias que lhe confere sentido e legitimidade, as imagens atuam como "operadores de memória", pois estão sempre retomando temas inscritos em uma rede de memórias, redefinindo-os na memória do presente ${ }^{16}$.

O que em última instância significa dizer que a construção imagética é marcada tanto pela memória visual quanto pela memória da língua. E isso não é diferente no caso das textualidades linguísticas. Ao se dizer "grávida", lembramos de imagens. Ao fotografar uma grávida, a imagem vem carregada de sentidos sobre o que se diz das grávidas.

O problema, no entanto, é que, do ponto de vista imagético, como significar uma doença ou uma epidemia absolutamente nova para a sociedade? Que imagens poderiam materializar sentidos tão novos?

O trabalho do Labic nos permite compreender quais foram as imagens referentes à epidemia e ao seu debate na internet que tiveram maior número de 'curtidas', que representam quantitativamente o número de acessos. Mas também, do ponto de vista discursivo, representam maior ou menor adesão dos sujeitos a certas práticas discursivas, a certos discursos.

De certa forma, o processo de produção desse material para análise se tornará um "arquivo de arquivos", e por isso mesmo um modo de registro da memória registrada - seja ela institucionalizada ou não, seja ela especializada ou própria de uma concepção cotidiana dessa epidemia. O que temos em mãos é um interessante arquivo analítico da memória icônico-discursiva que se formou sobre os primeiros meses mais dramáticos da epidemia, sem desconsiderar que para a formação de um material de análise sempre há recortes temporais, espaciais, temáticos etc.

Foram essas imagens que materializaram sentidos sobre a doença, mas que também ajudaram a constituir os próprios sentidos do que hoje a sociedade sabe sobre o Zika vírus. Foram elas que, em diálogo incessante com outras imagens de outras epidemias e de outras doenças, constituíram uma memória do dizer visual sobre a patologia Zika. São elas também que, ao circular, fazendo remissões ao que se diz linguisticamente, acabam por ser uma boa síntese dos discursos que atravessaram a sociedade naquele bimestre, quando a epidemia parecia se alastrar de forma impiedosa.

Quais foram as imagens que motivaram mais acessos e curtidas, e o que isso nos diz? Primeiramente, consideremos acessos e curtidas como práticas discursivas que se dão por preferências, predileções, identificações ou confiança entre sujeitos e textualidades. Essas práticas mantêm uma dupla relação com as posições discursivas ocupadas pelo sujeito. Tanto no acesso quanto na leitura.

Ao provocar malformações no feto, a epidemia de Zika acabou associada a uma espécie de epidemia de microcefalia, comumente subnotificada no Brasil. A revelação de que os casos de microcefalia estariam ligados

iii Mais à frente, referimo-nos também a arquivo analítico, o material organizado especialmente para a análise, e corpus,o material efetivamente analisado. Distinções que nos parecem úteis, dados os enormes desafios que hoje os processamentos automáticos de "arquivos digitais" impõem às análises discursivas. Se o discurso é marcado pela dispersão, é precisa não descuidar do fato de que a construção do arquivo analítico - a imagem das imagens analisada mais abaixo - é já objeto de recortes, escolhas metodológicas e condições materiais de pesquisa. E não somente o corpus, construído em etapa posterior. 
à incidência de Zika trouxe uma dramaticidade maior à doença, principalmente, pelo apelo jornalístico que lhe seguiu. Com isso, na memória do dizer, o vírus Zika passou a ser associado diretamente à gravidez principalmente pelos riscos que impunha.

Essa associação disparou um processo de busca compulsiva sobre notícias que relacionavam gravidez e vírus. Daí que boa parte das imagens presentes neste arquivo para análise refere-se à gravidez e aos riscos associados. Esta é a primeira relação com o sujeito-leitor da imagem. A Zika, como doença, presentifica o temor pelo risco à gravidez.

Mas o modo como essas imagens são apropriadas depende das posições ideológico-discursivas do leitor. Descuido governamental, situação de pobreza, falta de zelo da população, os modos de atribuição de sentidos às causas da epidemia de Zika são diversos e dependem da posição ocupada pelos sujeitos desse dizer coletivo aqui investigado.

É preciso lembrar que os sentidos estão sempre em constante deslocamento, sujeitos à história. Portanto, como uma enunciação aberta, o que for afirmado nesta análise só valerá exatamente, como numa espécie de fotografia, para o período anunciado. Outros acontecimentos, históricos, políticos, biológicos, sociais em suma, virão dar continuidade ao processo de produção, reprodução e deslocamento de sentidos sobre a epidemia de Zika.

Outra lembrança necessária é de que, do ponto de vista discursivo, sujeitos significam - seja por práticas de leitura, escrita, fala e escuta, ou mesmo compartilhamento de material significante - a partir de certas posições discursivas a que aderem por identificação. O sujeito é um lugar de significação historicamente constituído, ou seja, é uma posição. Em análise do discurso (AD), a posição-sujeito não significa presença física e nem mesmo lugares objetivos da estrutura social, mas um lugar social representado no discurso, sempre a partir de determinada formação discursiva (FD). "O sujeito diz, pensa que sabe o que diz, mas não tem acesso ou controle sobre o modo pelo qual os sentidos se constituem nele" ${ }^{\prime 1}$.

\section{Descrição e análise}

O Instagram é um aplicativo de rede social baseado em localização móvel que oferece aos usuários uma maneira de editar fotos, aplicar diferentes ferramentas de manipulação (filtros) para transformar a aparência da imagem e compartilhar instantaneamente com os outros usuários e amigos no próprio aplicativo ou em outras redes sociais, como Facebook, Foursquare, Twitter etc. ${ }^{(18)}$.

É um aplicativo que mistura o conceito de rede social com câmera fotográfica para celulares ou tablets. ${ }^{19} \mathrm{O}$ aplicativo possui uma ferramenta de busca, denominada "explorar". Por meio dela, é possível pesquisar usuários, hashtags e as fotos mais populares da rede social naquele momento. Hashtags são palavras-chave antecedidas pelo símbolo "\#” que designam um assunto específico, e que no Instagram funcionam como um agrupador de imagens relacionadas a determinado tema, facilitando a disseminação de um tópico e o acompanhamento de um conteúdo.

Algumas particularidades fazem do Instagram único, que, para Linaschke ${ }^{20}$, podem ser resumidas em duas palavras: fotografia e comunidade. Embora outras redes sociais, como Facebook e Twitter, por exemplo, também permitam o compartilhamento de imagens, apenas no Instagram o foco é a fotografia. Isso fica claro diante do fato de não ser possível postar sem uma foto ou um vídeo.

As imagens coletadas no Instagram a partir da hashtag \#zikavirus formaram uma "image cloud" (ou "nuvem de imagens") de acordo com sua importância e redundância. Considera-se o ImageCloud como um espaço discursivo, no qual é possível perceber o conjunto de imagens que mantêm relações de delimitação recíproca umas com as outras. As imagens falam entre si. Podemos, portanto, considerá-las, neste nosso objeto de estudo, enunciados de um processo discursivo em andamento, sabendo que todo discurso se delineia na relação com os outros: dizeres presentes e dizeres que se alojam na memória. 


\section{Arquivo e corpus}

Retomando o que dissemos anteriormente, vamos denominar arquivo discursivo aquilo que, da memória discursiva, da memória do dizer, fora registrado nos meios materiais disponíveis numa sociedade. E arquivo analítico (Figura 1) o material organizado especialmente para a análise. Essa organização envolve recorte, ponto de vista teórico, escolhas. Por outro lado, o corpus é aquilo que efetivamente será analisado.

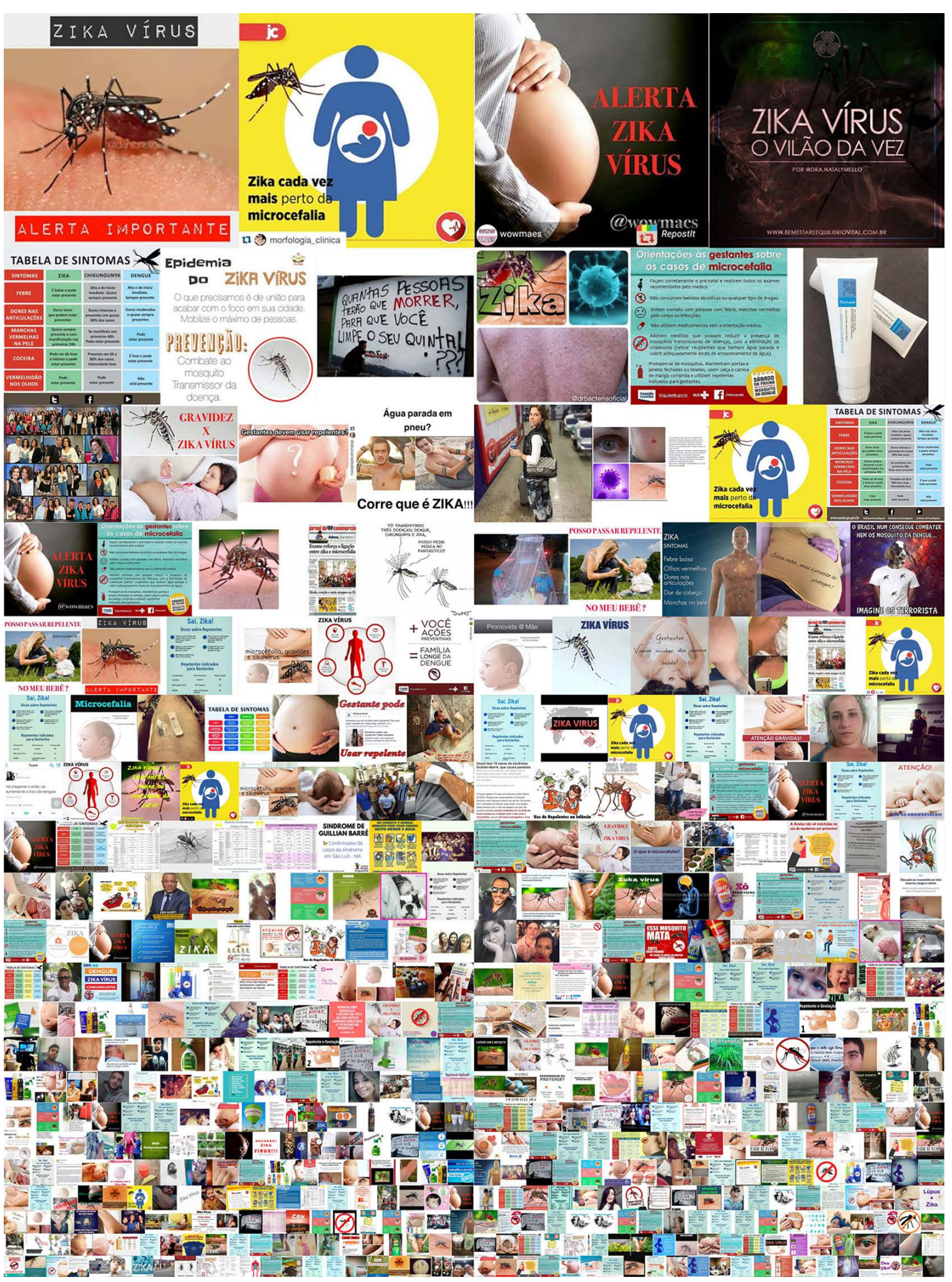

Figura 1. ImageCloud, no período de novembro e dezembro de 2015, ordenada de acordo com a quantidade de curtidas Fonte: Elaborada pelos autores. 


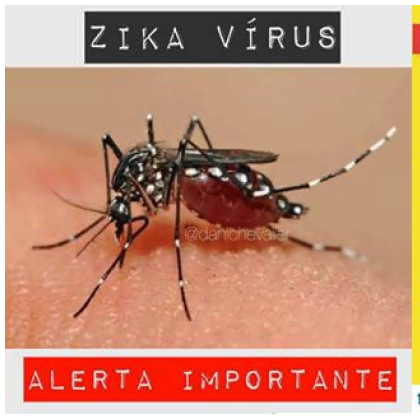

(1)

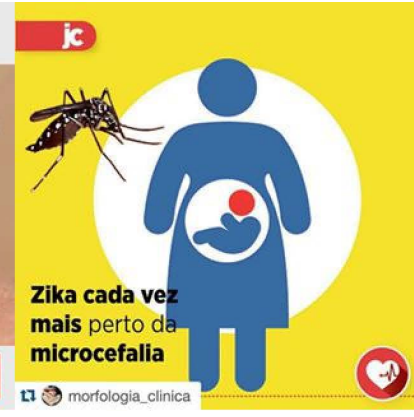

(2)

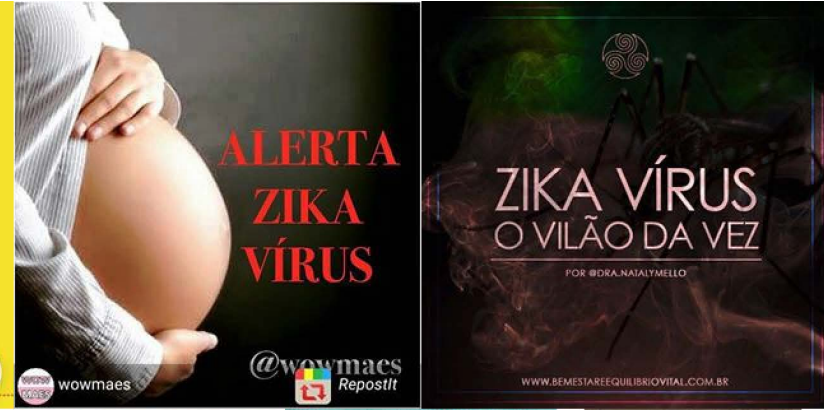

3

(4)
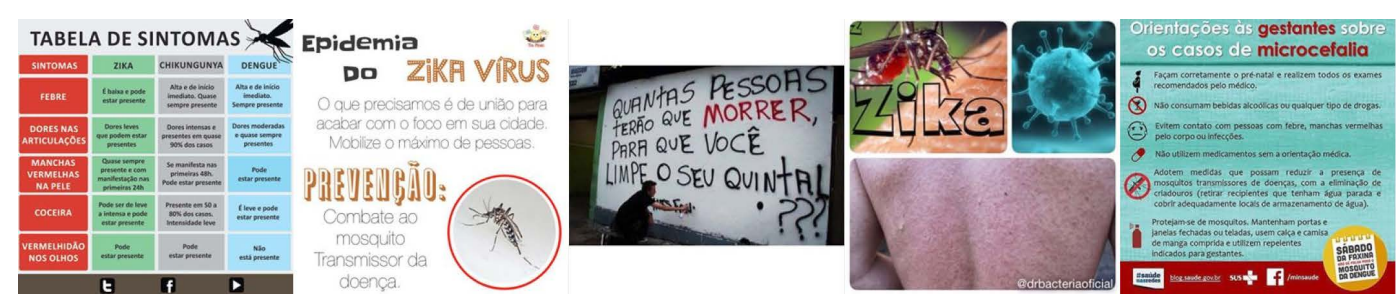

8

9

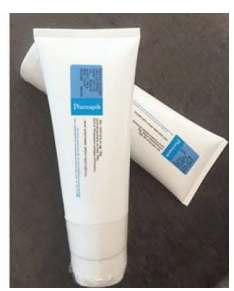

10

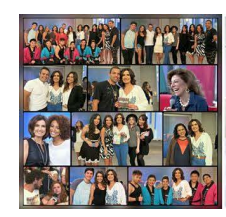

11

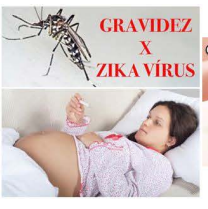

12

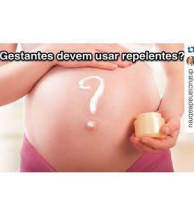

13

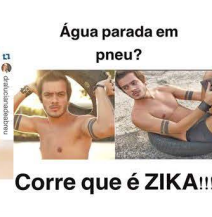

14

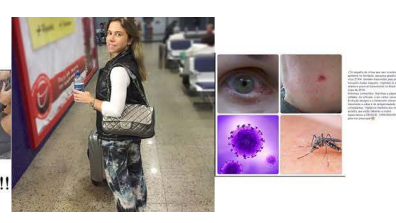

15

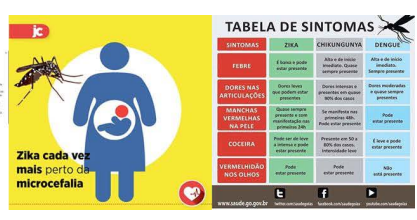

17

Figura 2. Sequência das 18 imagens que constituem o corpus Fonte: Elaborada pelos autores.

Como se pode observar, trata-se de uma imagem de imagens. Mas nos referiremos à primeira como 'arquivo analítico', porque foi construída, a partir de critérios e recortes, para fins de análise. Podemos dividir esse arquivo então em três partes. Cada uma mais ou menos correspondente a um terço da coleção de imagens, no sentido vertical.

O primeiro terço contém 18 imagens, a começar com a campanha pública em que aparece o mosquito Aedes aegypti, terminando com a segunda aparição da tabela de sintomas. É esta primeira seção do arquivo analítico que constituirá nosso corpus (Figura 2) - portanto, a sequência das 18 imagens, todas elas acompanhadas de textos linguísticos, que foram mais acessadas:

1. Imagem do inseto com a inscrição "Zika Vírus. Alerta importante".

2. O desenho de uma grávida com a inscrição: "Zika cada vez mais perto da microcefalia".

3. A foto da barriga de uma grávida, com a inscrição: "Alerta Zika vírus".

4. A imagem escura de um rosto de feto ao fundo e de um mosquito em sobreposição, com a inscrição: "Zika Vírus, o vilão da vez".

5. Uma tabela de sintomas colorida com referência às doenças transmitidas pelo vetor.

6. Um cartaz institucional em que aparece "Epidemia do Zika Vírus. Prevenção" em destaque.

7. Um cartaz não institucional, com um alerta dramático sobre a responsabilidade dos indivíduos pelas mortes.

8. Uma imagem tripla onde aparece a inscrição Zika, a imagem do mosquito, o vírus em azul e um corpo com manchas. 
9. Um novo cartaz institucional com orientação às grávidas.

10. A imagem de tubos de repelentes.

11. Um quadro com fotos de pessoas.

12. A imagem de uma grávida em posição de exame.

13. Novamente, a referência a uma grávida, desta vez em pé.

14. A imagem de um homem com uma frase sintética de alerta sobre a reprodução do vetor em água parada de pneus.

15. A imagem de uma mulher olhando para a câmera.

16. Uma quádrupla imagem: de um olho, de um mosquito sobre a pele, do vírus e de uma barriga, possivelmente de uma grávida.

17. Novamente a imagem referenciada no item 2.

18. Novamente a imagem referenciada no item 5.

No que diz respeito às materialidades significantes, a fotografia é predominante, aparecendo em 11 das 18 imagens. Algumas vezes com mais de uma referência. Uma mesma imagem com ilustração apareceu duas vezes: a da grávida com um bebê no útero, chamando a atenção para o crânio em vermelho. A repetição acontece quando mais de um usuário posta a mesma imagem em momentos diferentes. Também tivemos textos diagramados, em cores, com apresentação esquemática. O mosquito aparece nove vezes. Referências visuais a grávidas aparecem em seis oportunidades, mas à gravidez - como na imagem do crânio de um bebê com sobreposição da imagem do inseto, descrito no item 4 - bem mais vezes, inclusive nos textos diagramados.

Curiosamente, a imagem de um bebê diagnosticado com microcefalia só vai aparecer na seção intermediária - que está fora, portanto, desta análise. Ou seja, eis uma imagem que, com certeza, teve muitos acessos, mas não consta necessariamente entre as mais buscadas, compartilhadas e curtidas no Instagram durante o período analisado.

Há, portanto, uma incidência grande de referência aos riscos, maior do que a escolha por fotos de bebês afetados pelo vírus. Possivelmente, isso já marca uma diferença bem substancial em relação ao tratamento dado à epidemia por parte da imprensa. Pessoas compartilharam imagens de bebês com microcefalia, mas menos do que uma hipótese inicial poderia supor.

Quase todas as imagens apontam para a relação entre prevenção/risco. E a maioria delas é institucional. O que mostra que houve uma forte identificação dos sujeitos com discursos administrativos e especializados. Uma mesma tabela de sintomas apareceu duas vezes, mas a maior parte dos cartazes das imagens materializava uma prática discursiva, a do alerta.

Apesar disso, textos eminentemente linguísticos foram minoria. Imagens simples, com mensagens de impacto e alertas praticamente constituem majoritariamente esse thesaurus visual da epidemia. Ou seja, o discurso do alerta - ou risco - e da necessidade da prevenção foi aquele que teve maior adesão.

\section{Uma forma discursiva: o anúncio de injunção}

Práticas discursivas que visam a instrução, prescrição e orientação de modos de fazer podem ser compreendidas como 'injuntivas'. Há uma já extensa tradição de estudos sobre a injunção, tanto como ato de linguagem, pelo viés pragmático ${ }^{21}$, como por estudos de tipologia textual22. Interessa-nos, no entanto, compreender a injunção a partir de um ponto de vista discursivo, que leve em consideração o lugar projetado pelos sujeitos nas práticas injuntivas.

Como vimos na descrição, as imagens que tiveram mais acesso, como também as mais curtidas, foram aquelas que alertam para o risco e sugerem modos de prevenção, o que é um sintoma notável de mudança 
de comportamento do sujeito contemporâneo diante de uma epidemia. O que se percebe é o engajamento na circulação de informações e orientações acerca da epidemia em causa. São modos de agência marcados por um novo lugar na projeção imaginária das relações entre sujeito e mídia. Bem distintos daquela relação, não passiva, mas mais reativa em relação aos meios tradicionais.

A sétima imagem, na ordem que estabelecemos, é bem clara em relação a esse discurso de agência: “Quantas pessoas terão que morrer para que você limpe o seu quintal?”. Eis um texto que, por não ser institucionalizado, pode transcender os protocolos da comunicação oficial, para, em linguagem cotidiana, acentuar o caráter de alerta. Nada menos que o sétimo mais compartilhado na rede Instagram, o que demonstra um alto nível de adesão ao discurso. Mas, apesar da liberdade do cartaz acima mencionado, foram os discursos institucionalizados que produziram a maior quantidade de arquivos digitais.

Do ponto de vista discursivo, os efeitos de sustentabilidade são garantidos tanto pela recorrência aos pré-construídos quanto aos discursos transversos, que são os dois modos de realização da memória discursiva no dizer. Ao buscar acesso a uma imagem e principalmente ao compartilhá-la, o sujeito entra na sua cadeia - da imagem - de significação. Posiciona-se como um coautor de uma enunciação coletiva, uma textualidade que se dá na própria circulação de sentidos.

Ao compartilhar notícias e reportagens, artigos de opinião e análise, e também imagens, sejam fotográficas, diagramáticas, ilustrativas etc., o que se faz é dar continuidade a um processo enunciativo que pode se manter "ativo" por muito tempo. Pode-se considerar mesmo que estamos diante de outro modo de escrita, uma escrita coletiva como afirmado acima, que ganhou forma com o advento da web 2.o.

Os acessos, curtidas e compartilhamentos, portanto, podem ser compreendidos como processos enunciativos em curso e que, para a constituição de efeitos de sustentação se valem dos mesmos mecanismos utilizados na formulação tradicional - a escrita, a fala, a empresa pictórica etc.

De Frege, que pensou a pressuposição do ponto de vista lógico, a Ducrot, que trouxe a discussão para o seio da linguística, há uma larga tradição de reflexões sobre o que é dado como verdade sem que seja preciso dizê-lo: os pressupostos. $\mathrm{Na} \mathrm{AD}$, a pressuposição foi pensada como o 'pré-construído', aquilo que não precisa ser reafirmado como verdade - "aquilo que todo mundo sabe" ${ }^{13}$ - porque já alcançou um alto grau de consenso - mas não unanimidade - entre sujeitos sociais.

Mas, vemos também na produção desse arquivo discursivo a constante recorrência à palavra autorizada, ao saber institucionalizado, ao saber da verdade científica. No Instagram, o acesso e o compartilhamento de material institucional mostram que o sujeito do discurso na rede ainda tem a preocupação de se ancorar em um discurso legitimador. É nesse momento que ele se reconhece para se fazer sujeito do discurso. A articulação entre o seu dizer - a prática discursiva do acesso e do compartilhamento de imagens - e um discurso que está em outra região da memória - a autoridade governamental, a instituição, a ciência - é o que se denomina na $\mathrm{AD}$ de 'discurso transverso', também conceituado por Pêcheux ${ }^{13}$. Assim, tanto o préconstruído quanto o discurso transverso marcam a presença da memória discursiva na formulação do dizer.

Na tensão entre 'pré-construído' (aquilo que já se toma como verdade ou realidade) e discurso 'transverso' (aquilo que é reafirmado por uma voz autorizada e crível do que seja a "realidade") foi-se constituindo um arquivo poderoso que associa quase inevitavelmente - independentemente do grau e da realidade epidemiológica - Zika e prejuízos à gravidez, com o risco de malformações no feto.

\section{Memória do futuro: a responsabilização do indivíduo}

Como dissemos anteriormente, o acesso e o compartilhamento de imagens podem ser entendidos como um complexo processo de continuidade enunciativa, construído coletivamente. Eles vão estabelecendo não só uma grande textualidade, como um arquivo, e uma memória da doença e da epidemia. Até aqui entendemos que a prática discursiva predominante foi a injunção - instrução e prescrição. Foram 
privilegiados os discursos institucionalizados, e agora chegamos àquilo que parece alinhavar esses dois processos a uma questão ideológica: a responsabilização dos indivíduos pela doença.

Não há entre as imagens mais compartilhadas referências a desleixos do Estado, à falta de saneamento, à falha da atenção primária, a problemas no atendimento ao doente. Na mesma época, no entanto, boa parte da imprensa, talvez por posicionamentos políticos, vinha responsabilizando autoridades públicas pelo crescimento da epidemia. Não foi isso que se viu, se considerando o recorte temporal efetuado na produção deste arquivo analítico sobre a epidemia de Zika e a enunciação visual construída em rede em torno dela.

O que parece é que as mídias se dividiram naquele momento: a tradicional, jornalística, politizando a discussão; os acessos e compartilhamentos no Instagram institucionalizando a epidemia. Evidentemente, essas formulações e circulações de sentido não são alheias umas às outras. Ao longo do período analisado, não foram poucas as reportagens, as notícias, as recomendações de prevenção e o anúncio do risco. Mas podemos compreender que o arquivo constituído no Instagram deu menos atenção às implicações políticas da epidemia, e mais ao processo coletivo de cuidado e prevenção.

\section{Considerações finais}

Não precisamos nos alongar neste momento sobre a mudança paradigmática que instituiu uma responsabilidade maior do indivíduo pela saúde, à medida que as funções do Estado social vão sendo "desabilitadas" historicamente. Interessam-nos aqui os efeitos discursivos dessa mudança. Já a epidemia de HIV - e a culpabilização implícita à designação "grupo de risco" - ainda nos anos 1980 mostrava que a relação política entre sujeito e saúde estava em transformação.

Não é coincidência o fato de a epidemia de HIV ter merecido esse tratamento justamente na década em que forças neoliberais começam a destituir certas funções do Estado social. Lutas políticas, no entanto, foram travadas para que o Estado se impusesse no atendimento aos afetados pela doença.

Quase quatro décadas depois, o processo de responsabilização está mais que consolidado. Mas é preciso algum cuidado. Um estudo discursivo não pode deixar de atentar para o jogo dos sentidos, as disputas e intrigas entre os sujeitos em suas posições discursivas. Nesse jogo, o analista poderá compreender que formações ou matrizes de sentido predominam, em que textualidades, em que veículos, a partir de que público, no âmbito de que interlocuções.

Naquele momento em que as imagens foram compartilhadas, a "fotografia" dos sentidos nos mostrou a prevalência dessa formação discursiva tão pregnante em nossa sociedade contemporânea. $\mathrm{O}$ resultado poderia e pode ser diferente, se outro período fosse escolhido, outro veículo, outras textualidades, outras vivências. Afinal, discurso é movimento.

\section{Referências}

1. Delumeau, J. História do medo no Ocidente; 1300-1800. Tradução de Maria Lucia

2. Machado. São Paulo: Companhia das Letras; 2001.

3. Honorato, JI. Jornalismo e visualizações de dados: metodologia, questões e desafios. [trabalho de conclusão de curso]. Vitória: Universidade Federal do Espírito Santo; 2106.

4. Ministério da Saúde [Internet]. Confirmação do Zika Vírus no Brasil; 2015 - [citado em 2016 Ago 11]. Disponível em: http://portalsaude.saude.gov.br/index.php/o-ministerio/principal/secretarias/ svs/ noticias-svs/17702-confirmacao-do-zika-virus-no-brasil.

5. G1 [Internet]. Ministério da Saúde confirma 8 casos de zika vírus no RN e 8 na BA. 2015. [citado em 2016 Ago] Disponível em: http://g1.globo.com/bemestar/noticia/2015/05/ministerio-da-saudeconfirma-16-casos-de-zika-virus-no-brasil.html. 
6. Brasil. Ministério da Saúde [Internet]. Ministério da Saúde confirma relação entre vírus Zika e microcefalia. 2015. [citado em 2016 Ago] Disponível em: http://portalsaude.saude.gov.br/index.php/ cidadao/principal/agencia-saude/21014- ministerio-da-saude-confirma-relacao-entre-virus-zika-emicrocefalia.

7. Brasil. Ministério da Saúde, Gabinete do Ministro. Portaria No 1.813, de 11 de novembro de 2015. Declara Emergência em Saúde Pública de importância Nacional (ESPIN) por alteração do padrão de ocorrência de microcefalias no Brasil. [citado em 2016 Ago] Disponível em: http://bvsms.saude.gov.br/ bvs/saudelegis/gm/2015/prt1813 1111 2015.html.

8. World Health Organization [Internet]. Mosquito-borne diseases. [citado em 2016 Ago] Disponível em: http://www.who.int/neglected diseases/vector ecology/mosquito-borne-diseases/en/.

9. Beck U. La sociedad del riesgo. Hacia una nueva modernidad. Espanha: Paidós; 1998.

10. Bauman, Z. Medo líquido. Jorge Zahar: Rio de Janeiro; 2008.

11. Bauman Z. Danos colaterais. Desigualdades sociais numa era global. Jorge Zahar: Rio de Janeiro; 2013.

12. Birman J. O mal-estar na contemporaneidade. A psicanálise e as novas formas de subjetivação. Rio de Janeiro: Civilização Brasileira; 2003.

13. Courtine J. J. Analyse du discours politique: le discours communiste adressé aux chrétiens. Langages, $62 ; 1981$.

14. Pêcheux M. Semântica e discurso. Uma crítica à reafirmação do óbvio. Campinas, SP: Ed. Unicamp; 1997. p. 171.

15. Achard P. et al. Papel da memória. Campinas: Ed. Pontes; 2015. Pêcheux M. Papel da memória; p.49-58.

16. Orlandi EP. Discurso em análise: sujeito, sentido e ideologia. Campinas: Ed. Pontes; 2012.

17. Baracuhy MR. Análise do discurso e mídia: nas trilhas da identidade nordestina. Veredas ON LINE [internet]. 2010 [citado em 11 agos 2016]; 14(2):167-177. Disponível em: http://www.ufjf.br/ revistaveredas/files/2010/04/artigo-131.pdf.

18. Orlandi EP. Análise de discurso:princípios e procedimentos. Campinas, SP: Ed. Pontes; 2001.

19. Hochman N, Schwartz R. Visualizing Instagram: tracing cultural visual

20. Rhythms. International AAA1 Conference on Web Logs and Social Media, 6, 2012; Dublin. Proceedings... Menlo Park: AAAI Press; 2012.

21. Silva PIR. Instagram: um modo de narrar sobre si, fotografar ou de olhar para se ver. Congresso de Ciências da Comunicação na Região Sudeste ,17, 2012; Ouro Preto. Anais... Ouro Preto: Intercom, 2012. [Citado 15 set. 2009] Disponível em http://www.intercom.org.br/papers/regionais/sudeste2012/ resumos/R33-1626-2.pdf.

22. Linaschke J. Getting the most from Instagram. Berkeley: Peachpit Press; 2011.

23. Searle JR. Expressão e significado. São Paulo: Martins Fontes; 2002.

24. Travaglia LC. A superestrutura dos textos injuntivos. Estudos linguísticos/XXI Anais de Seminários do Grupo de Estudos Linguísticos do Estado de São Paulo - Vol.II. Jaú, Fundação Educacional Dr. Raul Bauab/GEL-SP; 1992. 